\title{
Occurrence of haploid and haploid/diploid mosaic embryos in untreated and androstenedione-immune Australian Merino sheep
}

\author{
J. D. Murray, M. P. Boland†, C. Moran*, R. Sutton, C. D. Nancarrow, \\ R. J. Scaramuzzi and R. M. Hoskinson
}

C.S.I.R.O. Division of Animal Production, P.O. Box 239, Blacktown, New South Wales 2148 and

*Department of Animal Husbandry, University of Sydney, Sydney, New South Wales 2006, Australia

\begin{abstract}
Summary. Chromosome counts were obtained from 73 out of $177(41 \%)$ early cleavagestage Merino embryos. A further 13 embryos were classified as probably diploid. Chromosome aberrations were found in $8(11 \%)$ embryos, one of which was aneuploid and the remainder $(9.6 \%)$ had euploid abnormalities. If the probable diploid embryos are included, the incidence of euploid aberrations falls to $8.1 \%$. Of the abnormal embryos there was one aneuploid with $2 \mathrm{~N}=55$, two haploids, four haploid/diploid mosaics and one zygote with 4 haploid metaphase plates. Two additional zygotes had 4 interphase pronuclei. Four of the euploid abnormalities were attributable to the entry of two or more spermatozoa and therefore polyspermy is the largest single factor leading to chromosomally aberrant embryos in this population of Merino ewes.
\end{abstract}

\section{Introduction}

The presence of chromosomal abnormalities has been correlated with early embryonic mortality in many mammals, including most of those of agricultural importance. Chromosome aberrations include aneuploidy ( $2 \mathrm{~N} \pm$ individual chromosomes), euploid abnormalities ( \pm whole chromosome sets) and a variety of structural rearrangements (reviews: Fechheimer, 1971; Gustavsson, 1980).

Estimates, which ignore hypodiploidy because individual chromosomes may be lost during processing, place the incidence of chromosomally aberrant embryos at between 0.6 and $10.5 \%$ in mammals (review table in Binkert \& Schmid, 1977). Polyploidy (principally $3 \mathrm{~N}$ ) represent a large proportion of the abnormalities occurring at a frequency of around $2-4 \%$ in mice, rabbits and hamsters (Binkert \& Schmid, 1977). The incidence of polyploidy is around $7 \%$ in cattle embryos at early stages (Gayerie de Abreu, Lamming \& Shaw, 1984) and drops to about $2 \%$ in blastocysts (Hare et al., 1980). Polyploidy has not been observed in sheep blastocysts or early cleavage-stage embryos (Long, 1977; Long \& Williams, 1980).

Haploidy and haploid/diploid $(1 \mathrm{~N} / 2 \mathrm{~N})$ mosaicism has rarely been reported in mammals, although it is relatively common $(2.4 \%)$ in early chicken embryos (Fechheimer, 1981). Beatty's (1957) summary lists 6 haploid and 1 haploid/diploid mosaic in a sample of 3731 mouse blastocysts. A further haploid embryo has been reported (Vickers, 1969) in the 994 early mouse embryos reported in the literature (see Binkert \& Schmid, 1977), giving an overall estimated frequency of haploidy and $1 \mathrm{~N} / 2 \mathrm{~N}$ mosaicism in the mouse of 0.15 and $0.02 \%$ respectively. Two haploid Chinese hamster embryos $(0.9 \%)$ have been reported (Binkert \& Schmid, 1977) and there is one case of a $1 \mathrm{~N} / 2 \mathrm{~N}$ mosaic rabbit blastocyst (Hansen-Melander \& Melander, 1971). The estimated level of

$\dagger$ Present address: Department of Agriculture, University College, Dublin, Lyons, Newcastle P.O., Ireland. 
haploidy and haploid/diploid mosaicism in cattle is $0 \cdot 14 \%$, as 2 haploids (Gayerie de Abreu $e$ al., 1984) and 2 mosaics (King, Linares, Gustavsson \& Bane, 1979; King, Linares \& Gustavsson, 1981) have been reported. A single $1 \mathrm{~N} / 2 \mathrm{~N}$ mosaic embryo was observed in a sample of $89(1.1 \%)$ earlystage sheep embryos (Long \& Williams, 1980).

The occurrence of haploid and haploid/diploid mosaic embryos in a sample of Australian Merino sheep was investigated in this study. A preliminary report described one of the haploid embryos and a zygote with 4 haploid divisions (Boland et al., 1984).

\section{Materials and Methods}

From 128 Merino ewes, 177 embryos ( $1-16$ cells) were collected $48-60 \mathrm{~h}$ after mating by surgically flushing the oviducts with $3-4 \mathrm{ml}$ phosphate-buffered saline (PBS: 0.01 M, pH 7.4) containing 5\% heat-inactivated sheep serum. Embryos at the $2-4$-cell stage were preferred over 8 cell embryos because they gave the highest yield of usable chromosome spreads ( 59 compared with $27 \% ; \chi^{2}=5.3, P<0.025$ ), thus the 48 -h collection time is recommended.

Ewes were synchronized in the previous oestrous cycle using progestagen-impregnated sponges (Repromap: Upjohn Pty Ltd, Rydalmere, New South Wales, Australia) and left untreated ( $\mathrm{N}=$ 48) or immunized against androstenedione-7-human serum albumin (Fecundin: Glaxo Animal Health Pty Ltd, Boronia, Victoria, Australia). Two injections of androstenedione-7-HSA were given, with the booster injection timed such that it was given 21 days after the primary injection and $14(\mathrm{~N}=38)$ or $25(\mathrm{~N}=42)$ days before expected mating. Ewes were exposed to 2 relays of harnessed, Merino rams ( $1 \mathrm{ram} / 15$ ewes), which were alternated at the morning and evening checks for oestrus. More detailed descriptions of the animal handling methods and full reproductive data will be published elsewhere.

Embryos were cultured in PBS containing $15 \%$ sheep serum, $0.8 \mu \mathrm{g}$ colchicine/ml, 100 i.u. penicillin $\mathrm{G} / \mathrm{ml}$ and $100 \mu \mathrm{g}$ streptomycin sulphate $/ \mathrm{ml}$ for $10 \mathrm{~h}$ at $37^{\circ} \mathrm{C}$ with a $5 \% \mathrm{CO}_{2}$ atmosphere before preparation for chromosomes by the method of Long \& Williams (1978). After embryos were individually transferred to clean slides and the excess hypotonic solution removed, one drop of methanol : acetic acid fixative $(1: 1, \mathrm{v} / \mathrm{v})$ was dropped onto the embryo from a height of $27 \mathrm{~cm}$. Chromosome preparations were stained in 5\% Giemsa in $0.004 \mathrm{M}$-phosphate buffer for $3.5 \mathrm{~min}$, airdried and mounted in DPX. All chromosome counts and sexing were confirmed by two of us (J.D.M. and C.M.).

\section{Results}

The chromosome complement was accurately determined for 73 out of 177 (41\%) embryos (Table 1). There were no significant differences between the untreated and immunized groups with respect to either the sex ratios or the incidence of chromosome abnormalities and so the data have been combined. There were 65 embryos with the normal diploid complement for sheep of 54 chromosomes and 8 embryos were chromosomally aberrant: 1 aneuploid $2 \mathrm{~N}=55$ and 7 with euploid abnormalities. The sex ratio of the embryos was not significantly different from the expected $1: 1$ ratio. Males were identified by the presence of a Y chromosome (P1. 1, Fig. 1), while females were identified by the absence of a $\mathrm{Y}$ chromosome because the $\mathrm{X}$ chromosome could not be reliably identified. The overall incidence of chromosomally abnormal embryos was $11.0 \%$, but the incidence of aneuploid and euploid abnormalities separately was 1.4 and $9.6 \%$ respectively. The chromosome complements of a further 13 embryos could not be accurately counted, because of inadequate spreading during fixation, but were near diploid ( 54). If these embryos were assumed to be normal and taken into account when calculating the incidence of euploid abnormalities, the frequency dropped to $8 \cdot 1 \%$. 


\section{PLATE 1}

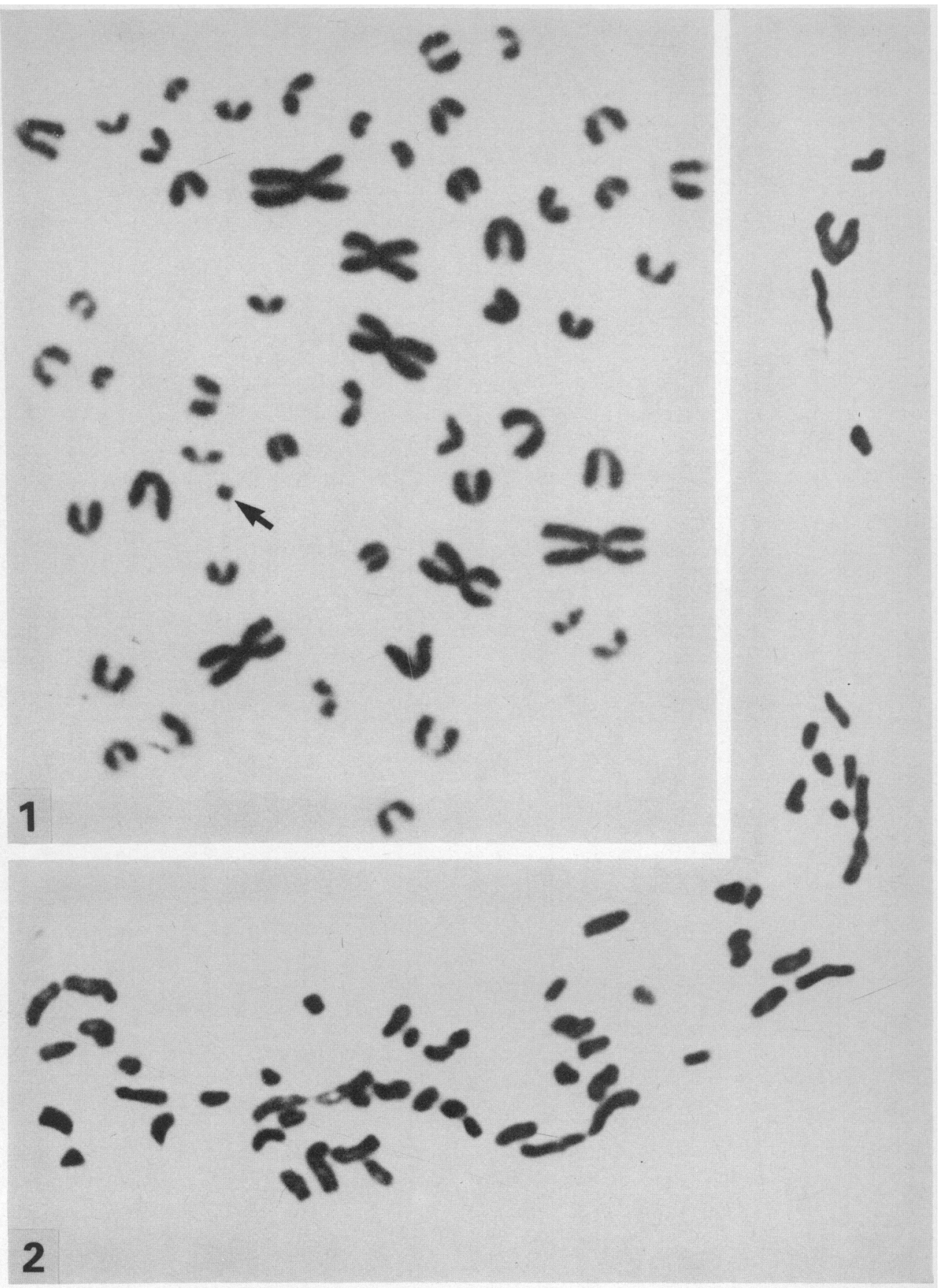

Fig. 1. $2 \mathrm{~N}=54 \mathrm{XY}$ cell from a 2-cell embryo. The $\mathrm{Y}$ chromosome is indicated by arrow. $\times 2600$.

Fig. 2. $2 \mathrm{~N}=55$ cell from a 2 -cell embryo. $\times 1640$. 


\section{PLATE 2}

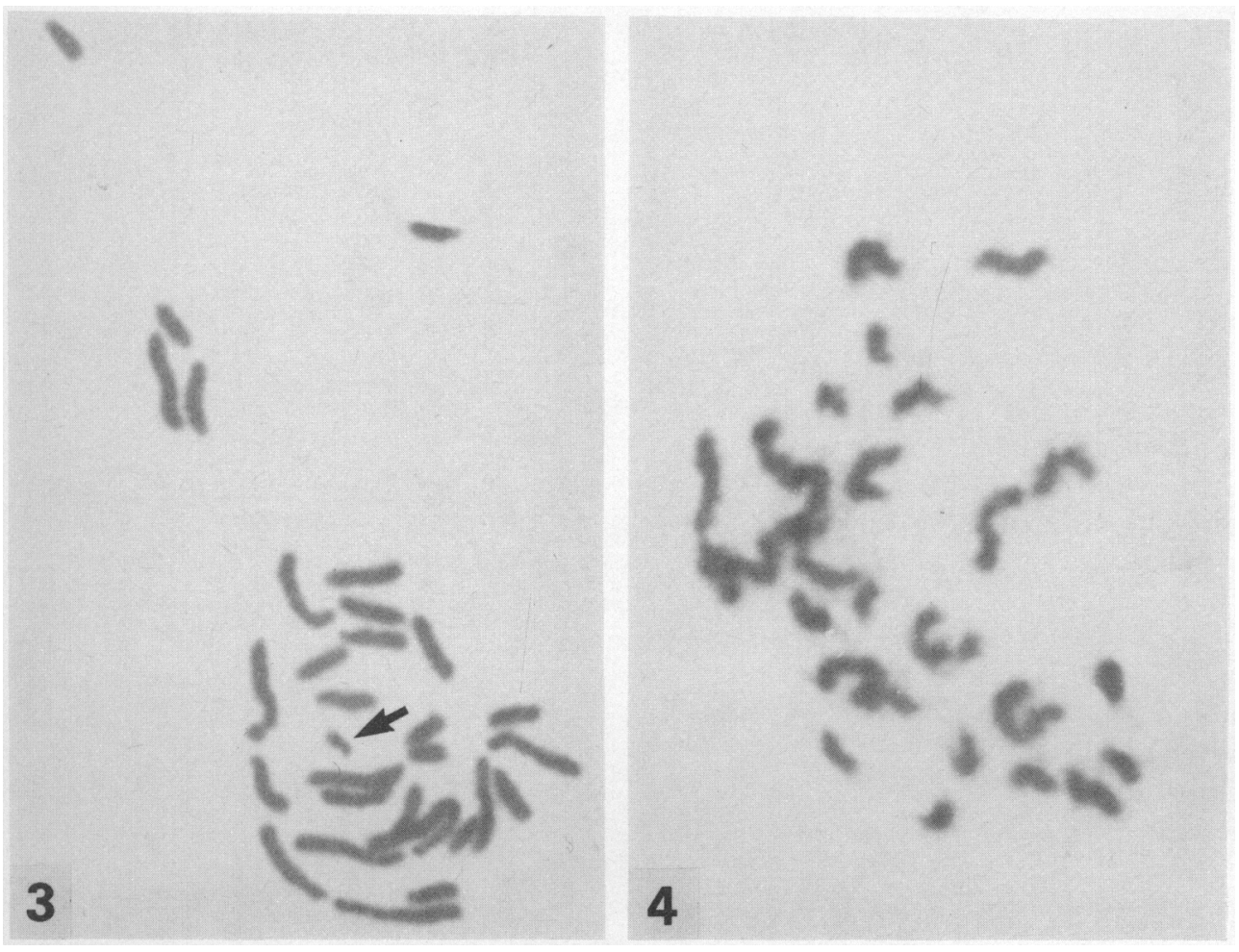

Fig. 3. $1 \mathrm{~N}=27$ cell from the zygote with four haploid divisions. $\mathrm{Y}$ chromosome indicated by arrow. $\times 1640$.

Fig. 4. Polar body division from a 4-cell embryo. $\times 2060$. 
Table 1. Number of embryos with normal $(2 \mathrm{~N}=54)$ and abnormal chromosome complements in Merino sheep

\begin{tabular}{|c|c|c|c|c|c|c|c|}
\hline \multirow{3}{*}{$\begin{array}{l}\text { Treatment } \\
\text { Group }\end{array}$} & \multicolumn{2}{|c|}{ No. of embryos } & \multirow{2}{*}{\multicolumn{2}{|c|}{ Normal }} & \multirow{2}{*}{\multicolumn{2}{|c|}{ Abnormal }} & \multirow{3}{*}{$\begin{array}{c}\% \\
\text { Abnorma }\end{array}$} \\
\hline & \multirow[b]{2}{*}{ Processed } & \multirow{2}{*}{$\begin{array}{c}\text { Yielding } \\
\text { Chromosomes }\end{array}$} & & & & & \\
\hline & & & $54 \mathrm{XX}$ & $54 X Y$ & Aneuploid & Euploid & \\
\hline $\begin{array}{l}\text { Control } \\
\text { Immunized* }\end{array}$ & 64 & 26 & 13 & 10 & 0 & 3 & 11.5 \\
\hline 14-days & 57 & 23 & 9 & 11 & 0 & 3 & 13.0 \\
\hline 25-days & 56 & 24 & 9 & 13 & 1 & 1 & $8 \cdot 3$ \\
\hline Totals & 177 & 73 & 31 & 34 & 1 & 7 & $11 \cdot 0$ \\
\hline
\end{tabular}

* Ewes immunized against androstenedione-7-HSA with booster injection given 14 or 25 days before expected mating.

The aneuploid embryo was female because no $\mathrm{Y}$ chromosome was detected in either of the two metaphase spreads scored. Both of the metaphase spreads were $2 \mathrm{~N}=55$, containing an additional unidentified acrocentric chromosome (Pl. 1, Fig. 2).

A zygote was observed with 4 haploid chromosome sets and a polar body division. Three of the divisions contained a $\mathrm{Y}$ chromosome and therefore were derived from spermatozoa (Pl. 2, Fig. 3). Two additional zygotes were observed with 4 interphase pronuclei each. Polar body divisions can usually be recognized as they tend to have an indistinct, fuzzy morphology (Pl. 2, Fig. 4).

The two haploid embryos were both 4-cell embryos and contained 2 and 3 haploid divisions respectively. These two embryos were female as no $\mathrm{Y}$ chromosomes were observed. There were spermatozoa on the zona pellucida of each of these embryos.

The remaining four abnormal embryos were $1 \mathrm{~N} / 2 \mathrm{~N}$ mosaics. One embryo contained 1 haploid and 2 diploid chromosome sets. The haploid division could not be sexed, but the diploid cells contained a $\mathrm{Y}$ chromosome. The remaining three $1 \mathrm{~N} / 2 \mathrm{~N}$ mosaic embryos each contained 2 diploid cells and 2 or more cells with haploid chromosome sets. In all 3 embryos, Y chromosomes were observed in the $1 \mathrm{~N}$ and $2 \mathrm{~N}$ cells.

\section{Discussion}

The incidence of chromosomally aberrant early-stage sheep embryos observed in this study was $11 \%$, with $1.4 \%$ being aneuploid and $9.6 \%$ being abnormalities involving entire chromosome sets. The overall frequency of embryos with abnormal chromosome complements reported here does not differ from the $6 \%$ incidence of aberrant sheep embryos reported by Long \& Williams (1980). However, the distribution of the types of aberrations between aneuploid and euploid abnormalities is different; we have found almost entirely euploid abnormalities ( 7 out of 8 ) while Long \& Williams (1980) reported only 1 out of 5 . This may be coincidental or it may reflect breed differences, as significant variation in the incidence of chromosome abnormalities in early embryos has been reported for different strains of mice (Beatty, 1957) and chickens (Fechheimer, 1981). The incidence of haploid and $1 \mathrm{~N} / 2 \mathrm{~N}$ mosaics reported in the present study $(7.9 \%)$ is considerably higher than the levels reported for other mammals $(0 \cdot 14-0.9 \%)$ or for chickens (see 'Introduction').

Aneuploidy in early-stage embryos most probably arises through meiotic non-disjunction as discussed by Long \& Williams (1980). Haploid embryos arise through egg activation without fertilization (or syngamy), whilst polyploid embryos are derived from the retention of a polar body, polyspermy or blastomere fusion (Beatty, 1957). Long \& Williams (1980) suggested that the $1 \mathrm{~N} / 2 \mathrm{~N}$ mosaic in their sample may have originated by polyspermy, but as the haploid cell did not have a $\mathrm{Y}$ 
chromosome there was no definite evidence for this suggestion. King et al. (1979) suggested that the $1 \mathrm{~N} / 2 \mathrm{~N}$ mosaic 2-cell cattle embryo in their sample represented retained mitotic activity of the polar body, rather than a product of polyspermy. However, in their later sample (King et al., 1981) they observed a one-cell embryo with 4 pronuclei indicating that polyspermy does occur in cattle.

Four of the abnormal embryos reported here and the 2 zygotes that contained 4 pronuclei each clearly resulted from polyspermy. These include the zygote with 4 haploid sets, 3 of which contained a $\mathrm{Y}$ chromosome, and the three $1 \mathrm{~N} / 2 \mathrm{~N}$ mosaic embryos which had $\mathrm{Y}$-bearing haploid and diploid metaphase chromosome sets. The presence of $\mathrm{Y}$ chromosomes in the haploid cells eliminates the possibility that these cells may have been unrecognized polar body divisions. It has previously been thought that polyspermy would lead to polyploidy (Austin, 1961; King et al., 1979) rather than to euploid mosaic conditions. In the cases reported here the second sperm-donated centrosome may have organized a second mitotic spindle leading to the production of haploid and diploid cells at the first or second cleavage division. In chickens the haploid cell lines in $1 \mathrm{~N} / 2 \mathrm{~N}$ mosaic birds are predominantly, if not entirely, derived from spermatozoa (Fechheimer, 1981). Alternatively, following the penetration of two spermatozoa the oocyte could have fragmented into two large cells, one of which contained two pronuclei with the other containing only one as reported in the pig (Hunter, 1967). The fact that one of the $1 \mathrm{~N} / 2 \mathrm{~N}$ mosaic embryos in this study was recorded as a morphologically normal 16-cell embryo at the time of collection supports these suggestions. The embryos were expected to be at the 2-4-cell stage because embryos would not normally reach the 16-cell stage until about $96 \mathrm{~h}$ after the onset of oestrus (Braden \& Baker, 1973). The 16-cell $1 \mathrm{~N} / 2 \mathrm{~N}$ mosaic embryo was collected no later than $76 \mathrm{~h}$ after the onset of oestrus and therefore should have contained no more than 8 cells.

The reasons for about $5 \%$ of the embryos being polyspermic are not clear. Delayed fertilization in the pig leads to an increase in polyspermy (Hunter, 1967), but natural matings were used in the present study and there is no reason to assume that there were any significant delays in the time of fertilization in the affected ewes.

The origin of the 2 haploid embryos is not clear, as both were female, but their chromosome complements could have been due to parthenogenesis, gynogenesis or androgenesis (Beatty, 1957). Parthenogenesis is the activation and development of an egg in the absence of fertilization, while both gynogenesis and androgenesis involve sperm penetration of the oocyte. Androgenesis would produce $\mathrm{X}$ and $\mathrm{Y}$ chromosome-bearing haploid embryos in equal frequencies, while the other routes could only produce haploid embryos with $\mathrm{X}$ chromosomes. As both of the haploid embryos were female there are no data to indicate the correct origin. However the presence of large numbers of spermatozoa attached to the surface of the zona pellucida of both embryos may support derivation from gynogenesis or androgenesis.

The haploid and haploid/diploid mosaic embryos would probably die early in development. Parthenogenetic haploid mouse embryos were found to be haploid/diploid mosaics by the egg cylinder stage (6.5-7.5 days) (Kaufman, 1978) with a proportion of these mouse embryos developing to the somite stage but most $(60-70 \%)$ dying around the time of implantation (Kaufman, Barton \& Surani, 1977).

The 8 abnormal embryos could be expected to be lost as Long (1977) did not find any chromosomally aberrant sheep blastocysts and, therefore the $11 \%$ level of chromosome abnormalities seen here represents the minimum amount of unavoidable embryonic wastage in this population of Merino ewes. Further work is in progress to determine the time at which these embryos are lost and more work will be needed to ascertain the factors that affect the degree of polyspermy in these sheep.

We thank the animal house staff, and in particular Mr J. Fenn, Mr J. Nobbs and Mr H. Thompson, for their assistance with the animals; and Miss A. Doff, Mr I. Hazelton, Mr N. Hamilton and Mr. J. Marshall for technical assistance. M.P.B. was the recipient of a Reserve Bank of Australia Fellowship while on leave from University College, Dublin. 


\section{References}

Austin, C.R. (1961) The Mammalian Egg. Blackwell Scientific Publications, Oxford.

Beatty, R.A. (1957) Parthenogenesis and Polyploidy in Mammalian Development. Cambridge University Press, Cambridge.

Binkert, F. \& Schmid, W. (1977) Pre-implantation embryos of chinese hamster. I. Incidence of karyotype anomalies in 226 control embryos. Mutation Res. 46, 63-76.

Boland, M.P., Murray, J.D., Scaramuzzi, R.J., Moran, C., Sutton, R., Hoskinson, R.M., Hazelton, I.G. \& Nancarrow, C.D. (1984) Reproductive wastage and early embryonic chromosomal abnormalities in immunized and control Merino ewes. In Review of Research in Sheep Reproduction, pp. 137-139. Eds D. R. Lindsay \& D. T. Pearce. Australian Academy of Science, Canberra.

Braden, A.W.H. \& Baker, A.A. (1973) Reproduction in sheep and cattle. In The Pastoral Industries of Australia, pp. 269-302. Eds G. Alexander \& O. B. Williams. Sydney University Press, Sydney.

Fechheimer, N.S. (1971) Cytogenetic considerations in animal breeding. Annls Genet. Sel. anim. 3, 43-58.

Fechheimer, N.S. (1981) Origins of heteroploidy in chicken embryos. Poultry Sci. 60, 1365-1371.

Gayerie de Abreu, F., Lamming, G.E. \& Shaw, R.C. (1984) A cytogenetic investigation of early stage bovine embryos-relation with embryo mortality. Proc. 10th Int. Congr. Anim. Reprod. \& A. I., Urbana; Brief Commun. 2, 82, Abstr.

Gustavsson, I. (1980) Chromosome aberrations and their influence on the reproductive performance of domestic animals-a review. Z. Tierzuchtz. Zuchtgsbiol. 97, 176-195.

Hansen-Melander, E. \& Melander, Y. (1971) A case of spontaneous haploidy and notes on triploiddiploid mosaics in rabbit embryos. Hereditas 67, 83-88.
Hare, W.C.D., Singh, E.L., Betteridge, K.J., Eaglesome, M.D., Randall, G.C.B., Mitchell, D., Bilton, R.J. \& Trounson, A.O. (1980) Chromosomal analysis of 159 bovine embryos collected 12 to 18 days after estrus. Can. J. Genet. Cytol. 22, 615-626.

Hunter, R.H.F. (1967) The effects of delayed insemination on fertilization and early cleavage in the pig. $J$. Reprod. Fert. 13, 133-149.

Kaufman, M.H. (1978) Chromosome analysis of early post implantation presumptive haploid parthenogenetic mouse embryos. J. Embryol. exp. Morph. 45, 85-91.

Kaufman, M.H., Barton, S.C. \& Surani, M.A.H. (1977) Normal post implantation development of mouse parthenogenetic embryos to the forelimb bud stage. Nature, London. 265, 53-55.

King, W.A., Linares, T., Gustavsson, I. \& Bane, A. (1979) A method for preparation of chromosomes from bovine zygotes and blastocysts. Vet. Sci. Commun. 3, $51-56$

King, W.A., Linares, T. \& Gustavsson, I. (1981) Cytogenetics of preimplantation embryos sired by bulls heterozygous for the 1/29 translocation. Hereditas 94, 219-224.

Long, S.E. (1977) Cytogenetic examination of preimplantation blastocysts of ewes mated to rams heterozygous for the Massey I $\left(t_{i}\right)$ translocation. Cytogenet. Cell Genet. 18, 82-89.

Long, S.E. \& Williams, C. (1978) Chromosomal abnormalities in ova and zygotes from normal ewes mated to normal rams. Vet. Rec. 102, 153.

Long, S.E. \& Williams, C.V. (1980) Frequency of chromosomal abnormalities in early embryos of the domestic sheep (Ovis aries). J. Reprod. Fert. 58, 197201.

Vickers, A.D. (1969) Delayed fertilization and chromosomal anomalies in the mouse embryo. J. Reprod. Fert. 20, 69-76.

Received 3 October 1984 